\title{
Mining Enterprises Development as a Financial Source of Environmental Activities in Mining Regions
}

\author{
Victoria Frolova ${ }^{1, *}$, Olga Dolina $^{1}$, and Tatyana Shpilkina ${ }^{2}$ \\ ${ }^{1}$ Financial University under the Government of the Russian Federation, 125993 Leningradsky Prospekt \\ 49, Moscow, Russia, \\ ${ }^{2}$ Moscow Automobile and Road Construction State Technical University (MADI), 125319 Leningradsky \\ prospect 64, Moscow, Russia
}

\begin{abstract}
The analysis of using the production capacity and other economic indicators of mining enterprises is given and the structure of goals of a development strategy in mining industry is shown. An example of mining effective methods that do not cause environmental damage to the regions is described. The authors emphasize that the development of regions and their ecology are in close interdependence with the participation of extractive companies in economic and social infrastructure development, their costs for environmental protection. They substantiate the methodology for the growth rates analysis of mining companies' costs for environmental protection measures. It is carried out separately for each type of expenditure, average for the year and cumulative over a period of time to optimize the sources of financing for targeted development programs for mining regions and improve their ecology.
\end{abstract}

\section{Introduction}

Modern system of economic relations, actively changing external environment of business make new demands for the criteria of assessing the effectiveness of companies, which ultimately should be reflected in the positive dynamics of economic and social development, in improving the ecology of the region. In recent years the problem of environmental safety has become urgent due to imperfect environmental control and limited financial resources of the state and mining enterprises for environmental protection measures. Raw material dominance in the structure of the Russian economy causes a number of economic and financial problems, and therefore it is urgent to develop a strategy for the development of mining industry in such a way that it supplies raw materials to such important sectors as engineering, metallurgy and chemical industry, agriculture, power engineering.

\footnotetext{
* Corresponding author: academy@,fa.ru
} 


\section{Materials and Methods}

As the statistics show, in the processing industries, for which raw materials are the results of mining enterprises, there are significant reserves of unused production capacity (Table 1).

Table 1. The use level of the average annual production capacity of organizations for manufacturing a certain product type in 2010-2015 (\%) [1].

\begin{tabular}{|l|c|c|c|c|c|}
\hline Indicators & $\mathbf{2 0 1 0}$ & $\mathbf{2 0 1 2}$ & $\mathbf{2 0 1 3}$ & $\mathbf{2 0 1 4}$ & $\mathbf{2 0 1 5}$ \\
\hline Extraction of minerals: coal & 77 & 81 & 80 & 81 & 82 \\
\hline $\begin{array}{l}\text { Metallurgical production } \\
\text { and production of finished } \\
\text { metal products: cast iron }\end{array}$ & 90 & 88 & 92 & 93 & 94 \\
\hline $\begin{array}{l}\text { Machinery and equipment } \\
\text { production: tractors for } \\
\text { agriculture and forestry, } \\
\text { others }\end{array}$ & 25 & 40 & 19 & 16 & 11 \\
\hline Cars & 57 & 80 & 68 & 59 & 43 \\
\hline Trucks & 31 & 47 & 45 & 39 & 34 \\
\hline
\end{tabular}

In such conditions, the economy structure needs to be optimized on the basis of an integrated approach to the development of concepts and programs for ensuring environmental safety and social-and-economic development of regions, taking into account their providing with necessary resources and growth potential (Fig. 1).

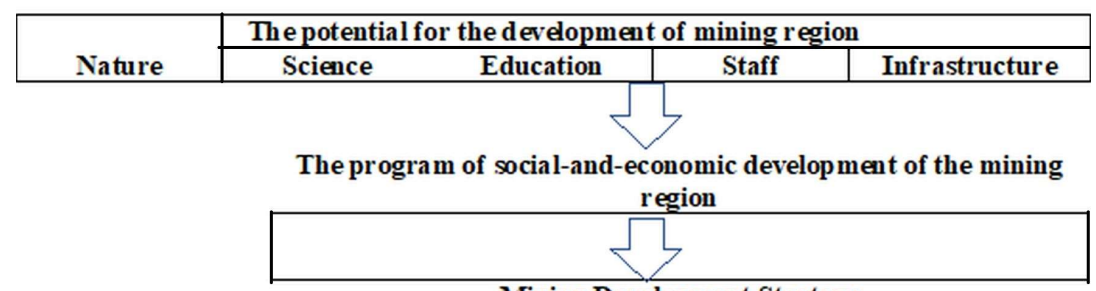

Mining Development Strategy

Fig. 1. The formation of mining development strategy.

The development and implementation of programs for the development of mining regions and their environmental safety requires significant financial costs. In the conditions of limited funds of state budgets, it is expedient to use multi-channel financing [2]. Sources of financing for such projects can be both state budget funds and special funds based on joint activities of the state and business within the framework of public-private partnership.

For the last period, there has been a positive trend in the economic performance of mining enterprises (table 2).

Table 2. Indicators of organizations engaged in the extraction of minerals in 2003-2016 (except fuel and energy companies) [3].

\begin{tabular}{|l|c|c|c|c|}
\hline Indicators & $\mathbf{2 0 0 3}$ & $\mathbf{2 0 0 5}$ & $\mathbf{2 0 1 5}$ & $\mathbf{2 0 1 6}$ \\
\hline $\begin{array}{l}\text { Balanced financial result (profit } \\
\text { minus loss) (in actual prices, } \\
\text { million rubles) }\end{array}$ & 28709 & 105974 & 271632 & 672700 \\
\hline Share of profitable organizations,\% & 51.2 & 61.3 & 55.7 & 73.7 \\
\hline Profitability of sold products,\% & 23.8 & 42.8 & 47.5 & 54.7 \\
\hline
\end{tabular}


As follows from the indicators of Table 2, the positive financial results of enterprises' activities engaged in mining operations can be a source of investment in the development of mining regions and improving the environment in them.

Studies of environmental issues in mining regions at different periods of time were conducted by Askarov Z.F., Askarov R.A., Chuenkov G.A., Golik V.I., Maslennikov S.A., Yermishina E.B., Kapralova I.A., Vas'kovtsova Ya.S. [4-5].

The dependence of companies' economic growth on the level of resources extraction is reflected in the works of A.A. Peshkov, N.A. Matsko. [6], Social-and-economic support of mining regions is analyzed in the works of Oydup T.M., Adadimova L.Yu., Oidup Ch.K. Serpuhovitina T.Yu., Zhilinkova A.P. [7-8].

\section{Results and Discussion}

The actual problem of mining companies is the extraction of minerals by the most effective methods and at the same time not causing the ecological damage to the region in which they are located. In this regard, the development of the Irkutsk Company "Helios", organized in 2012-2013, is of interest. The company "Helios", consisting partly of the Irkutsk National Research Technical University (INRTU) staff, tried to modify the existing technology of mining. The head of the company "Helios" Mr. Davydenko - a native of the Siberian Geophysical Research and Production Company, deals with electrical exploration for oil and gas companies on the differential-normalized method of electrical prospecting (DNMEP).

Employees of the company came to the conclusion that it is necessary to change the technology for geological exploration at a depth of more than $100 \mathrm{~m}$. This need is explained by the fact that what is on the surface that had already been found and needs to be reoriented to new requests of the mining industry. The company "Helios" for several years has been dealing with this problem, and it managed to develop a technology for electrical exploration of electromagnetic sounding and induced polarization (EMS-IP). According to Mr. Davydenko 15 million rubles had been spent for that for the first 3-4 years. [9].

The financial support of the company was provided by the Assistance Foundation to the Development of Small Enterprises in the Scientific and Technical Sphere (Bortnik Foundation). At the same time, the company began cooperation with Almazy Anabara Company, for which Helios performed the processing of previously collected data and then supplied its equipment. It turned out that the search for deposits by this method is more effective than other technologies [9].

In 2015-2016 years the company "Helios" performed experimental electric exploration searching for ore gold in the Altai Republic and poly-metallic ores in the Altai Territory at depths of up to 700 meters. In the conclusion of Rosgeology it was said that the effectiveness of the technology as one of the exploration technique for poly-metallic ores is $77 \%$ against the industry average of $30 \%$. According to S. Fedak, the chief geologist of the Gorno-Altai Expedition, this is one of the most accurate methods of exploration of poly-metallic ores. It shows areas of increased polarization of rocks, in addition, this method allows constructing three-dimensional models of rock exploration to detect hidden anomalies.

To date, EMS-IP shows the best results in the exploration of poly-metals, gold and copper. In total, since "Helios" entered the market, 40 wells had been drilled taking into account its forecasts, more than $90 \%$ of which turned out to be sulfide mineralization, with about half the ore intervals were identified. As the head of the "Helios" company said this had been good statistics for the industry. According to the results of experimental and methodological work, "Helios" received several positive conclusions, but the company has no large orders yet. Currently, "Helios" deals with the provision of data processing and adaptation services. In 2017 , the company's turnover was 23 million rubles, the profit was about 1.5 million rubles. 
It should be noted that the effectiveness of the method developed by "Helios" has yet to be proved. In addition, it must gain recognition and enter the register of geological exploration methods along with other methods. It should also be noted that this method of EMS-IP is applicable not only to the exploration of minerals, but also can be used in the search for hydrothermal sources [9-10].

We believe that the use of EMS-IP method developed by "Helios", in the long term, can increase the volume of rock mining by mining enterprises, which will improve their efficiency in general.

In this regard, it is important to note that the study of 15 largest mining companies conducted by the authors showed that the development of regions, territorial infrastructure, and social security of the population is largely carried out by the companies themselves, and not at the expense of budgets. In addition, the authors found active participation of companies in the development of environmental measures. It is especially important, as the environmental culture of production, in accordance with modern requirements, is the main criterion for the activities of companies.

The main financial characteristic of environmental measures implementation is the amount of costs for ongoing activities, as well as the dynamics of total costs and for individual items of expenditure over a number of time periods. It should be noted that the dynamics of costs for the entire observation period followed the level of inflation and in some periods was even in advance of it. The total costs of companies for environmental protection activities consists of the costs for protecting the air, water, subsoil, waste management, use, rehabilitation of land, scientific developments, payment for negative impact, including fines, and other activities. The dynamics and cost structure by the example of a major company Alrosa is presented in Table 3 .

Table 3. The dynamics of organization's cost structure for environmental protection activities for 20122016 (million rubles).

\begin{tabular}{|l|c|c|c|c|c|c|}
\hline \multicolumn{1}{|c|}{ Indicators } & $\mathbf{2 0 1 2}$ & $\mathbf{2 0 1 3}$ & $\mathbf{2 0 1 4}$ & $\mathbf{2 0 1 5}$ & $\mathbf{2 0 1 6}$ & Total \\
\hline $\begin{array}{l}\text { Research and development } \\
\text { activities to reduce negative } \\
\text { anthropogenic environmental } \\
\text { impacts }\end{array}$ & 39.6 & 44.8 & 27.6 & 15.5 & 21.3 & 148.8 \\
\hline $\begin{array}{l}\text { Protection of atmospheric air } \\
\text { and prevention of climate } \\
\text { change }\end{array}$ & 122.1 & 126.7 & 86.9 & 84.8 & 91.5 & 512.0 \\
\hline $\begin{array}{l}\text { Wastewater collection and } \\
\text { treatment }\end{array}$ & 1 & 701.6 & 908.3 & 989.3 & 930.0 & 5128.2 \\
\hline Waste management & 155.4 & 324.6 & 352.4 & 382.7 & 252.6 & 1467.7 \\
\hline $\begin{array}{l}\text { Protection and rehabilitation of } \\
\text { lands. surface and groundwater }\end{array}$ & 714.3 & 1429.9 & 1 & 1680.5 & 1774.1 & 7055.1 \\
\hline $\begin{array}{l}\text { Protection of the environment } \\
\text { from noise. vibration and other } \\
\text { physical effects }\end{array}$ & 0.036 & 0.382 & 0.351 & 0.546 & 0.612 & 1.9 \\
\hline $\begin{array}{l}\text { Ensuring radiation safety of } \\
\text { environment }\end{array}$ & 0.08 & & & 0.012 & & 0.1 \\
\hline $\begin{array}{l}\text { Conservation of biodiversity } \\
\text { and protection of natural areas }\end{array}$ & & & 0.372 & 0.705 & & 1.1 \\
\hline $\begin{array}{l}\text { Other activities in the field of } \\
\text { environmental protection }\end{array}$ & 0.418 & 9.3 & 11.9 & 33.1 & 19.4 & 74.1 \\
\hline
\end{tabular}

To assess the stability of ongoing environmental measures, the growth rates of costs were calculated (Table 4). 
Table 4. The growth rate of environmental protection costs for 2012-2016.

\begin{tabular}{|l|c|c|c|c|}
\hline \multicolumn{2}{|c|}{ Expenditures } & \multicolumn{4}{c|}{ Growth rate } \\
\cline { 2 - 5 } & $\begin{array}{c}\mathbf{2 0 1 3} / \\
\mathbf{2 0 1 2}\end{array}$ & $\begin{array}{c}\mathbf{2 0 1 4} / \\
\mathbf{2 0 1 3}\end{array}$ & $\begin{array}{c}\mathbf{2 0 1 5} / \\
\mathbf{2 0 1 4}\end{array}$ & $\begin{array}{c}\mathbf{2 0 1 6} \\
\mathbf{2 0 1 5}\end{array}$ \\
\hline $\begin{array}{l}\text { Research and development activities to reduce } \\
\text { negative anthropogenic environmental } \\
\text { impacts }\end{array}$ & 1.13 & 0.62 & 0.56 & 1.37 \\
\hline $\begin{array}{l}\text { Protection of atmospheric air and prevention } \\
\text { of climate change }\end{array}$ & 1.04 & 0.69 & 0.98 & 1.08 \\
\hline Wastewater collection and treatment & 0.44 & 1.29 & 1.09 & 0.94 \\
\hline Waste management & 2.09 & 1.09 & 1.09 & 0.66 \\
\hline $\begin{array}{l}\text { Protection and rehabilitation of lands. surface } \\
\text { and groundwater }\end{array}$ & 2.00 & 1.02 & 1.15 & 1.06 \\
\hline $\begin{array}{l}\text { Protection of the environment from noise. } \\
\text { vibration and other physical effects }\end{array}$ & 10.61 & 0.92 & 1.56 & 1.12 \\
\hline $\begin{array}{l}\text { Conservation of biodiversity and protection of } \\
\text { natural areas }\end{array}$ & & & 1.90 & \\
\hline $\begin{array}{l}\text { Other activities in the field of environmental } \\
\text { protection }\end{array}$ & 22.25 & 1.28 & 2.78 & 0.59 \\
\hline
\end{tabular}

The average growth rate for all types of environmental protection expenditures showed a trend proportional to the general economic situation in Russia (see Table 5 and Figure 1). The average growth rate for the total cost of environmental protection measures is determined by the formula:

$$
\overline{T p l}=\sqrt[k]{\operatorname{Tp} 1 * T p 2 * \ldots * T p k}
$$

where $\overline{\mathrm{Tp} \iota}$ is an average growth rate for all types of costs;

$\mathrm{k}$ is the sequence number of the cost element.

The average growth rate for the period is determined by the formula:

$$
\overline{T p}=\sqrt[n-1]{\operatorname{Tp} 1 * T p 2 * \ldots * T p n}
$$

where $\overline{\mathrm{Tp}}$ is an average growth rate over a number of periods for all types of costs; $\mathrm{n}$ is the sequence number of the time period.

The results of the calculation are presented in Table 5.

Table 5. The average value of the growth rates of environmental protection costs for 2012-2016

\begin{tabular}{|l|c|}
\hline \multicolumn{1}{|c|}{ Period of time } & Average growth rate \\
\hline $2013 / 2012$ & 1.998468079 \\
\hline $2014 / 2013$ & 0.962831915 \\
\hline $2015 / 2014$ & 1.22327608 \\
\hline $2016 / 2015$ & 0.951304282 \\
\hline $2012-2016$ & 1.308269478 \\
\hline
\end{tabular}

The decrease in the aggregate growth rates of environmental expenditures of Alrosa in comparison with the growth rates of environmental conditions change can be seen in Figure 2 . The decrease in 2014 relative to 2013 occurred against the backdrop of the economic crisis and sanctions, and in 2016, relative to 2015, there was a reduction in prices and the level of inflation. 


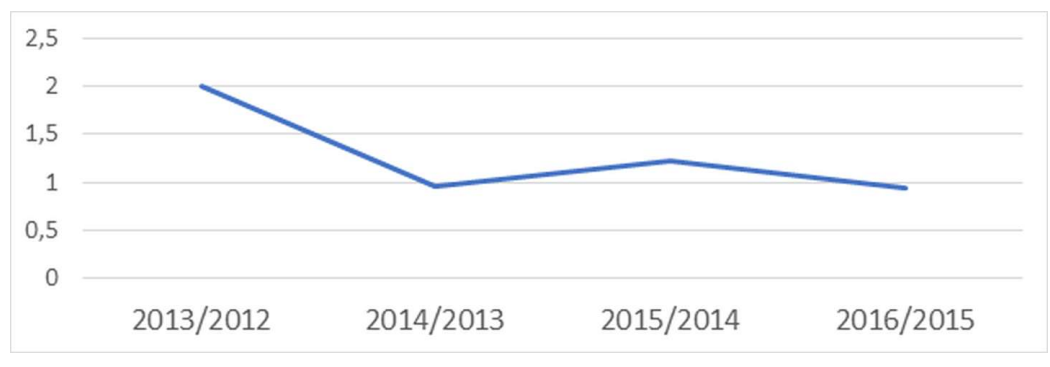

Fig. 2. The dynamics of average growth rates of costs for environmental activities in 2013-2016

\section{Conclusion}

In the opinion of the authors, the application of the methodology for analyzing the growth rates of environmental protection costs separately for each type of expenditure, the average for the year and the cumulative over the period is universal. The comparison of growth rates and bringing to the integral cumulative growth rate allows comparing with other companies within the industry, other types of activity, and also making a rating of companies' participation in environment protection measures, etc. In addition, it is possible to identify the trend of changes in indicators and the construction of forecast indicators.

Thus, based on the studies carried out, the following conclusions can be made:

1. The development of the region is closely related to the participation of extractive companies in landscaping, social support, environmental activities.

2. There is a high need to update the territorial social-and-economic infrastructure in the regions.

3. It is necessary to carry out measures for the reproduction of natural resources, optimization of projects for deposit development, rational use of raw materials and waste processing in the sphere of ecology.

4. The environmental safety of production and the regions as a whole should be accompanied by the development of new saving production technologies, a high level of working and living conditions, through the comprehensive modernization of production with the goal of creating integrated production and ecological systems.

5. It is expedient to use multi-channel financing for development programs for mining regions in the conditions of limited funds of state budgets. It is advisable to analyze and plan the costs of mining enterprises for environmental measures in accordance with the methodology of analyzing the costs' growth rates.

\section{References}

1. Rosstat, Macroeconomic Statistics. URL: http://gks.ru

2. V. Frolova, O. Dolina, T. Shpil'kina, E3S Web Conf., 21, 04018 (2017)

3. Rosstat, National Accounts.

URL: http://www.gks.ru/wps/wcm/connect/rosstat_main/rosstat/ru/statistics/accounts/

4. V. Golik, Y. Dmitrak, E3S Web Conf., 21, 01018 (2017)

5. V. I. Golik, S. A. Maslennikov, E.B. Ermishina, Problems of Regional Ecology, 4. 168173 (2012)

6. A. A. Peshkov, N. A. Matsko, Mining informational and analytical bulletin, 2:12, 264-274 (2009). 
7. A. V. Myaskov, S. M. Popov, Economics and Innovation Management, 1, 16-24 (2018). DOI: $10.26730 / 2587-5574-2018-1-16-24$

8. E. Dotsenko, E3S Web of Conf., 21, 04013 (2017)

9. E. Shavina, O. Kalenov, E3S Web of Conf., 21, 04025 (2017)

10. E. Dotsenko, N. Ezdina, A. Prilepskaya, K. Pivnyk, E3S Web of Conf., 21, 04014 (2017) 